\title{
Population Dynamics of Solenopsis Mealybug Parasitoid, Aenasius arizonesis (Girault) on Cotton and Other Alternate Host Plants
}

\author{
Vijaya and Dharmendar Singh*
}

Department of Entomology, CCSHAU Hisar-125004, Haryana, India

*Corresponding author

\begin{tabular}{|l|}
\hline Ke y w o r d s \\
Solenopsis \\
Mealybug \\
Parasitoid, \\
Aenasius arizonesis \\
(Girault), Cotton
\end{tabular}

\section{A B S T R A C T}

Solenopsis mealy bug Phenacoccus solenopsis Tinsley has emerged as a major threat to cotton cultivation in India since past few years. Aenasius areizonesisi Girault has been found to parasitize solenopsis mealy bug. The present study results showed during the months of April to June 2009, parasitization of $\mathrm{P}$. solenopsis was found to be ranging from 16.4 per cent to 66.66 per cent on the alternate host plants i.e. Hibiscus rosa sinensis, Parthenium hysterophorus, Acyranthes aspera, Abutilon indicum, Xanthium strumarium, Datura metel and on cotton sprouts etc. From July onwards, the mealybug colonies started appearing on the main cotton crop, the parasitization also increased gradually from 47.43 to 55.66 per cent during July to August. It was concluded from the above studies that Aenasius arizonesis can be a potential agent for the biological control of solenopsis mealybug, Phenacoccus solenopsis. A. arizonesis can effectively check P. solenopsis population surviving a wide range of temperature conditions causing upto 76.62 per cent parasitization in the crop season and 74.82 per cent during the off-season.

\section{Introduction}

Solenopsis mealybug, Phenacoccus solenopsis, Tinsley has emerged as a serious threat to cotton cultivation in India. The mealybugs suck the cell sap from leaves, twigs, stems, roots and fruiting bodies. Cotton plants infested during vegetative phase exhibit symptoms of distorted and bushy shoots, crinkled and/or twisted and bunchy leaves, and stunted plants that dry completely in severe conditions. In the Indian subcontinent, the pest has caused widespread and serious damage to cotton crop (Abbas et al., 2005; Dhawan et al., 2007; Jhala et al., 2008; Saini et al., 2009).

Aenasius arizonesis (Girault) is an important parasitoid of P. solenopsis (Ram et al., 2009). Surveys in cotton growing areas of Haryana 
showed 23.7 to 76.6 per cent parasitisation of P. solenopsis by A. arizonesis on cotton (Ram and Saini, 2010). The present study was conducted to know the parasitization extent of the parasitoid on cotton and other alternate host plants during the course of study time.

\section{Materials and Methods}

Mealybug infested twigs of cotton and other plants were collected at 15 days interval during April 2009 to July 2010 from areas around Hisar and other parts of Haryana. The plants included were Abutilon indicum (Linn.), Parthenium hysterophorus L., Datura metel L., Cenchrus ciliaris L., Xanthium strumarium L., Hibiscus rosa-sinensis Cooperis, Helianthus annus L. etc. along with the main host plant i.e. Gossypium spp. Plant parts (twigs) infested with mealybugs were brought to the laboratory and number of mealybugs on the twigs was counted and the twigs were kept in glass jars $(20 \times 15 \mathrm{~cm})$ tightly covered with muslin cloth with the help of rubber bands at room temperature $\left(23.2-33^{\circ} \mathrm{C}\right)$ for further rearing.

The mealybugs parasitized by A. arizonesis transformed into reddish brown mummies. Such mummies were counted, removed from the twigs and transferred to glass vials $(7.5 \times 1$ $\mathrm{cm}$ ) for obtaining adult parasitoids. When no more mummies were formed, the sample was discarded. Number of adult parasitoids emerging from the mummies was recorded daily. The sample was discarded when the adults ceased to emerge from the mummies. The adult parasitoids were sorted under the stereozoom binocular microscope and were preserved in 70 per cent alcohol for further identification.

Per cent parasitisation by primary parasitoid per sample was calculated as: (Total number of mummies / Total number of mummies and surviving mealybugs) $\times 100$

\section{Results and Discussion}

Population dynamics of Aenasius arizonesis

\section{Parasitization of $P$. solenopsis by $A$. arizonesis under field conditions}

The data presented in Table 1 revealed that the parasitoid, A. arizonesis of $P$. solenopsis throughout the year except in the winter months of January-February when no colonies of the pest were seen. During the months of April to June 2009, parasitization of $P$. solenopsis was found to be ranging from 16.4 per cent to 66.66 per cent on the alternate host plants i.e. Hibiscus rosa sinensis, Parthenium hysterophorus, Acyranthes aspera, Abutilon indicum, Xanthium strumarium, Datura metel and on cotton sprouts etc.

From July onwards, the mealybug colonies started appearing on the main cotton crop, the parasitization also increased gradually from 47.43 to 55.66 per cent during July to August (Plate VII).

However during end August $(24.31 \%)$ and first fortnight of September (13.47 \%) a decline in parasitization was recorded.

During October-November 2009 per cent parasitization ranged from 34.42 to 53.06 per cent. During December, parasitization decreased to 10 per cent probably due to very low temperature prevailing during that period. During January-February, probably due to severe cold conditions no mealybug colonies were observed and hence no parasitization was recorded.

During winter season, the pest probably survived in the stacks of cotton sticks or under the dried leaves of its other host plants or in soil and the parasitoid might have survived in the mummified mealybugs until the favourable temperature prevailed. 
Table.1 Parasitization of Phenacoccus solenopsis by the parasitoid Aenasius arizonesis on cotton and/or other alternate host plants during 2009-10

\begin{tabular}{|c|c|c|c|c|c|c|c|c|c|}
\hline $\begin{array}{l}\text { Date of } \\
\text { collection }\end{array}$ & Host plants & $\begin{array}{c}\text { Parasitisation } \\
(\%)\end{array}$ & $\begin{array}{l}\text { Max. } \\
\text { Temp. } \\
\left({ }^{0} \mathrm{C}\right)\end{array}$ & $\begin{array}{c}\text { Min. } \\
\text { Temp. } \\
\left({ }^{0} \mathrm{C}\right)\end{array}$ & $\begin{array}{c}\text { Avg. } \\
\text { Temp. } \\
\left({ }^{\circ} \mathrm{C}\right)\end{array}$ & $\begin{array}{l}\text { Morn. } \\
\text { R.H. } \\
(\%)\end{array}$ & $\begin{array}{l}\text { Eve. } \\
\text { R.H. } \\
(\%)\end{array}$ & $\begin{array}{l}\text { Avg. } \\
\text { R.H. } \\
(\%)\end{array}$ & $\begin{array}{c}\text { Total } \\
\text { Rainfall } \\
(\mathrm{mm})\end{array}$ \\
\hline 1-4-2009 & A. indicum & 66.66 & 30 & 13.9 & 21.9 & 91 & 43 & 67 & 4.1 \\
\hline $15-4-2009$ & Cotton sprouts & 45.52 & 34.2 & 16.3 & 25.3 & 78 & 46 & 62 & 24.9 \\
\hline $30-4-2009$ & A. indicum & 25.23 & 37.3 & 18.3 & 27.8 & 47 & 13 & 30 & 0 \\
\hline $15-5-2009$ & A. indicum & 61.53 & 39.8 & 22.5 & 31.1 & 52 & 21 & 37 & 0 \\
\hline $31-5-2009$ & P. hysterophorus & 34.4 & 41.8 & 24.8 & 33.1 & 57 & 30 & 44 & 38.2 \\
\hline $15-6-2009$ & A. indicum & 16.4 & 41.4 & 24.4 & 34.8 & 57 & 27 & 4 & 24.9 \\
\hline $30-6-2009$ & Cotton sprouts & 33.93 & 41.9 & 26.1 & 33.9 & 53 & 24 & 38 & 5 \\
\hline 15-7-2009 & Cotton & 47.43 & 37.1 & 25.8 & 31.4 & 77 & 57 & 67 & 28.5 \\
\hline $31-7-2009$ & Cotton & 51.89 & 36.3 & 26.9 & 31.5 & 79 & 59 & 68.5 & 63.9 \\
\hline $15-8-2009$ & Cotton & 55.86 & 39.7 & 28.2 & 33.9 & 69 & 45 & 57 & 0 \\
\hline 31-8-2009 & A. indicum & 24.31 & 36.4 & 25.5 & 32.9 & 83 & 54 & 68.3 & 14 \\
\hline $15-9-2009$ & Cotton & 13.4 & 32.6 & 22.8 & 27.7 & 73 & 65 & 79 & 239.9 \\
\hline $30-9-2009$ & Cotton & 76.62 & 36.2 & 22.2 & 29.1 & 84 & 37 & 61 & 0 \\
\hline $15-10-2009$ & Cotton & 39.61 & 34.6 & 19.3 & 27 & 84 & 34 & 57 & 0 \\
\hline $31-10-2009$ & Cotton & 53.06 & 32.3 & 12 & 22.1 & 85 & 24 & 54.8 & 0 \\
\hline $15-11-2009$ & Cotton & 34.42 & 28.6 & 13.3 & 20.9 & 89 & 47 & 68 & 0 \\
\hline $30-11-2009$ & Cotton & 39.94 & 25.7 & 6.4 & 17 & 93 & 35 & 64.7 & 0 \\
\hline 15-12-2009 & Cotton & 19.63 & 24.5 & 7.4 & 15.9 & 88 & 37 & 63 & 0 \\
\hline $31-12-2009$ & A. indicum & 10 & 21.8 & 2.7 & 12.2 & 91 & 36 & 63.2 & 0 \\
\hline $15-3-2010$ & A. indicum & 12.5 & 31.5 & 14.2 & 22.9 & 82 & 35 & 61 & 2.5 \\
\hline $30-3-2010$ & A. indicum & 10.38 & 38.1 & 19.2 & 28.6 & 74 & 26 & 51.1 & 0 \\
\hline $15-4-2010$ & A. indicum & 30.55 & 39.8 & 17.8 & 30.8 & 61 & 19 & 40 & 0 \\
\hline $30-4-2010$ & A. indicum & 29.01 & 42.4 & 23 & 32.7 & 41 & 16 & 29.1 & 0 \\
\hline $15-5-2010$ & A. indicum & 37.66 & 41.5 & 23.3 & 32.4 & 53 & 20 & 37 & 1.9 \\
\hline $30-5-2010$ & H. rosa-sinensis & 5.29 & 44.2 & 25.4 & 34.7 & 41 & 16 & 28.6 & 0 \\
\hline $15-6-2010$ & H. rosa-sinensis & 28.57 & 38.7 & 23.8 & 31.2 & 62 & 34 & 49 & 47.8 \\
\hline $30-6-2010$ & H. rosa-sinensis & 14.36 & 42.2 & 27.8 & 34.9 & 58 & 32 & 45.2 & 2.5 \\
\hline $15-7-2010$ & A. indicum & 16.37 & 36.3 & 26.2 & 31.2 & 86 & 63 & 75 & 71.9 \\
\hline $31-7-2010$ & P. hysterophorus & 74.87 & 34.3 & 26.6 & 32.1 & 89 & 68 & 77 & 228.1 \\
\hline $15-8-2010$ & A. indicum & 56.64 & 34.1 & 26.2 & 31.1 & 90 & 67 & 79 & 66.6 \\
\hline $31-8-2010$ & A. indicum & 10.52 & 33.5 & 25.2 & 31.5 & 93 & 72 & 82.6 & 143.3 \\
\hline
\end{tabular}

*No collections were made from January-February as during this time period no mealybug colony was observed on the alternate host plants perhaps due to the prevailing severe cold conditions

Table.2 Correlation coefficient between weather parameters and per cent parasitization by Aenasius arizonesis on cotton and alternate host plants (weeds) during 2009 and 2010

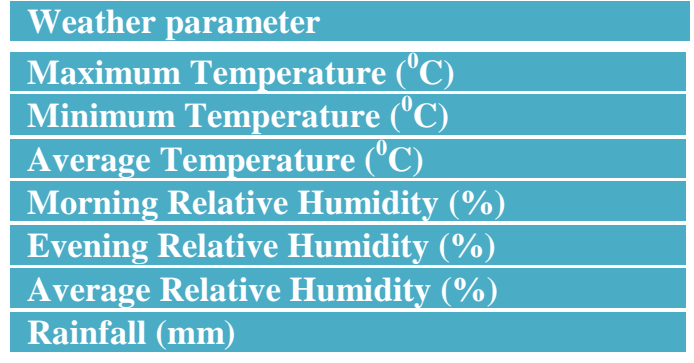

\begin{tabular}{|c|}
\hline Correlation Coefficient \\
\hline-0.02 \\
\hline 0.11 \\
\hline 0.04 \\
\hline 0.23 \\
\hline 0.17 \\
\hline 0.21 \\
\hline 0.04 \\
\hline
\end{tabular}


In March, 2010, mealybug colonies started appearing on weeds like Abutilon indicum. Mealybug parasitization was very low in March (10.38-12.50 \%) and it started increasing gradually and the parasitization reached to 37.66 per cent in first fortnight of May, 2010. The parasitization declined in second fortnight of May, 2010 (5.29 \%) and remained low upto second fortnight of July, 2010 probably due to high temperature. High parasitization $(74.87 \%)$ was recorded in second fortnight of July, 2010. During August, 2010 parasitization declined considerably to 10.52 per cent in the second fortnight.

\section{Correlation coefficient between per cent parasitization and weather parameters}

As evident from the data in Table 2, there was no significant effect of the weather parameters on the parasitization of Phenacoccus solenopsis by the parasitoid, Aenasius arizonesis on cotton and other alternate host plants. However, stage of the host plant, stage of the pest and hyper parasitization might play an important role in the fluctuation of the parasitization.

The parasitoid, A. arizonesis parasitized $P$. solenopsis on cotton and other alternate host plants throughout the year except in the winter months of January-February when no colonies of the pest were seen causing 13.476.6 per cent parasitization during crop season and 5.2-74.8 per cent during offseason on alternate host plants like Hibiscus rosa sinensis, Parthenium hysterophorus, Acyranthes aspera, Abutilon indicum, Xanthium strumarium, Datura metel and on cotton sprouts etc. Ram and Saini (2010) also reported that during 2009, parasitization of solenopsis mealybug by $A$. arizonesis was observed on cotton throughout the crop growing season causing upto 76.6 per cent parasitization. Similarly, different workers like Mahmood (2008) reported more than 50 per cent parasitization, Tanwar et al., (2008) reported 20-70 per cent parasitization and Ram et al., (2009) reported 37.6-72.3 per cent parasitization of $P$. solenopsis by Aenasius sp. on cotton and other host plants.

\section{Correlation between per cent parasitization and weather parameters}

It was seen that there was no significant effect of the weather parameters like temperature, relative humidity and rainfall on the parasitization of $P$. solenopsis by the parasitoid, A. arizonesis on cotton and other alternate host plants. However, stage of the host plant, stage of the pest and hyperparasitization might play an important role in the fluctuation of the parasitization.

It was concluded from the above studies that Aenasius arizonesis can be a potential agent for the biological control of solenopsis mealybug, Phenacoccus solenopsis. A. arizonesis can effectively check $P$. solenopsis population surviving a wide range of temperature conditions causing upto 76.62 per cent parasitization in the crop season and 74.82 per cent during the off-season.

\section{References}

Abbas, G., Arif, M. J. and Saeed, S. 2005. Systematic status of new species of new genus Phenacoccus cockerell. (Pseudococcidae) a serious pest of cotton Gossypium hirsutum L. in Pakistan. Pakistan Entomology 27: 8384.

Dhawan, A. K., Singh, K., Saini, S. Mohindru, B., Kaur, A. Singh, G. and Singh, S. 2007. Incidence and damage potential of mealybug, Phenacoccus solenopsis Tinsley on cotton in Punjab. Indian Journal of Ecology 34: 110-116. 
Jhala, R. C., Bharpoda, T. M. and Patel, M. G. 2008. Phenacoccus solenopsis Tinsley (Hemiptera: Pseudococcidae), the mealybug species recorded first time on cotton and its alternate host plants in Gujarat, India. Uttar Pradesh Journal of of Zoology 28(3): 403-406.

Mahmood, R. (2008). Breakthrough in biological control of cotton mealybug in Pakistan. Biocontrol News and Information 29 (3): 38-39.

Ram, P. and Saini, R. K. 2010. Biological control of solenopsis mealybug, Phenacoccus solenopsis Tinsley on cotton: a typical example of fortuitous biological control. Journal of Biological Control, 24 (2): 104-109.

Ram, P., Saini, R. K. and Vijaya, 2009. Preliminary studies on field parasitization and biology of solenopsis mealybug parasitoid, Aenasius bambawalei Hayat (Encyrtidae: Hymenoptera). J. Cotton. Res. Dev., 23 (2): 313-315.

Saini, R. K., Ram, P., Sharma, S. S. and Rohilla, H. R., 2009. Mealybug, Phenacoccus solenopsis Tinsley and its survival in cotton ecosystem in Haryana, 150 pp. In: Proceedings of National Symposium on Bt-Cotton: Opportunities and Prospectus. Central Institute of Cotton Research, Nagpur, November 17-19, 2009.

Tanwar, R. K., Bhamare, V. K., Ramamurthy, V. V., Hayat, M., Jeyakumar, P., Singh, A. and Bhambawalei, O. M. 2008. Record of new parasitoids on mealybug, Phenacoccus solenopsis. Indian Journal of Entomology 70(4): 404-405.

\section{How to cite this article:}

Vijaya and Dharmendar Singh. 2018. Population Dynamics of Solenopsis Mealybug Parasitoid, Aenasius arizonesis (Girault) on Cotton and Other Alternate Host Plants. Int.J.Curr.Microbiol.App.Sci. 7(08): 171-175. doi: https://doi.org/10.20546/ijcmas.2018.708.022 